\title{
Commercial Charcoal Production and Sustainable Community Development of the Upper West Region, Ghana
}

\author{
Kwasi Osei Agyeman \\ Department of Planning \\ Kwame Nkrumah University of Science and Technology, Kumasi, Ghana \\ E-mail: kwasi.1955@yahoo.com \\ Owusu Amponsah \\ Department of Planning \\ Kwame Nkrumah University of Science and Technology, Kumasi, Ghana \\ E-mail: amponsah_owusu@yahoo.co.uk \\ Imoro Braimah \\ Department of Planning \\ Kwame Nkrumah University of Science and Technology, Kumasi, Ghana \\ E-mail: ibraimah2002@yahoo.com
}

Stephen Lurumuah

Jaman South District Assembly, Ghana

E-mail: luristephen@yahoo.com

Received: November 1, 2011

Accepted: March 2, 2012 Published: April 1, 2012

doi: $10.5539 /$ jsd.v5n4p149

URL: http://dx.doi.org/10.5539/jsd.v5n4p149

\begin{abstract}
Policy discussions have suggested a complete ban on charcoal production and the introduction of substitutes to meet the energy needs of the growing number of consumers. These discussions are fuelled by the effects of the charcoal industry's activitities on the environment. On the contrary, the authors of this paper highlight the need to sustain the charcoal industry in the Upper West Region of Ghana. This conclusion was arrived at through an analysis of the charcoal industry's role in economic development of some communities in the Upper West Region. Data gathered from 500 commercial charcoal producers and 50 charcoal buyers indicated that commercial charcoal production is a major source of livelihood. While charcoal producers earned monthly incomes of about GHф200, the buyers’ earned between GHф82 - 2343 per month. Despite its economic importance, the industry’s environmental problems are enormous. These were attributed to the extraction of raw materials, mainly live trees, from the natural forest without replacement. The authors concluded that the way forward towards sustainable economic development through charcoal production lies in the adoption of efficient charcoal production technologies.
\end{abstract}

Keywords: Commercial, Charcoal production, Sustainable development, Upper west region

\section{Background to the Paper}

Majority of African households depend on traditional fuels to meet their daily energy needs and this is most likely to continue for many years to come (Kituyi, 2002; Mwampamba, 2007). The use of wood fuel as household cooking fuel and for any other form of domestic heating is thus very much relevant in sub-Saharan Africa (SSA) (Erakhrumen, 2008 cited in Erakhrumen, Ogunsanwo \& Ajewole, 2010). Available estimates indicate that over $90 \%$ of the people in Africa depend on either firewood or charcoal for cooking and other heat applications (Kituyi, 2002; Temu, 2002 cited in Erakhrumen et al., 2010). Similarly, in Ghana, the bulk of 
energy supply is from wood fuel which accounts for about $65 \%$ of the country's energy supply mix (Energy Commission, 2010a; Ottu-Danquah, 2010). Charcoal is the dominant energy used by urban households in Ghana. Charcoal use as household cooking fuel accounts for about $52.6 \%$ of total household energy consumption-mix (Ghana Statistical Service, 2008). The number of households that depend on wood fuel for the supply of their daily energy needs is projected to increase continuously (Food and Agricultural Organisation (FAO) 1999 cited in Erakhrumen et al, 2010). Hosier (1993) cited in Mwampamba (2007) indicated that as African cities grow more charcoal would be consumed. They estimated that for each $1 \%$ increase in urbanisation there is a $14 \%$ increase in charcoal consumption. Msuya, Masanja and Temu (2011) also revealed that Tanzania losses 150,433 hectares of forest, equivalent to about $5.8 \%$ of the forest per year due to fuel wood consumption. Erakhrumen (2010) identifies demographic and socio-economic changes, and unpredictable fluctuations in the prices of fuels (such as kerosene, liquefied petroleum gas (LPG), and others) as the factors that account for the projected future increases in fuelwood consumption. These statistics underscore the importance of charcoal as a domestic and commercial fuel in SSA in general and Ghana in particular.

The bulk of the charcoal produced in Ghana is from the savannah regions of the country and most especially among the Sissalas in the Upper West Region of Ghana (Songsore, 2003). Coincidentally, the charcoal producing areas of the northern part of Ghana are poverty endemic. For example, the Ghana Statistical Service (2008) estimates the incidence of poverty in the Upper West to be $80 \%$ which happens to be the highest in Ghana. Eight out of every ten people are poor in the Region (Government of Ghana, 2003). A significant proportion of its population (around half or more) is extremely vulnerable and food insecure. Currently, $34 \%$ of the region's population is food insecure; the highest in Ghana and an additional $13 \%$ is vulnerable to food insecurity (World Food Programme, 2009 cited in Inkoom and Nanguo, 2011).

The Government of Ghana (GoG, 2003) and the Environmental Protection Agency (EPA, 2005) attribute the high incidence of poverty and food insecurity in the region to the single rainfall regime which supports one-season rain-fed agriculture. As a consequence of poverty, out-migration from the Upper West Region is the highest in Ghana. The Ghana Statistical Service (2005) indicates that due to the high intensity of out-migration, a third (about 31\%) of the Upper West Region's population lives in other regions. As a coping strategy, the remaining households living in these poverty endemic areas have diversified their livelihood sources. Commercial charcoal production is, thus, a significant source of livelihood providing incomes to support households especially during the long dry seasons (Guo, 2007; Ottu-Danquah, 2010; Songsore, 2003). Guo (2007) adds that charcoal is not a major source of cooking fuel for rural households but rather a source of off-farm income in the long lean seasons.

As exemplified by Hardin's theory of "The Tragedy of the Commons" in 1968, the commercial charcoal producers obtain their raw materials for the production of charcoal from the forest which they consider a common-property resource for their individual economic satisfaction (Ghatak, 2005; Hardin, 1968 cited in Lurumuah, 2011). This phenomenon is supported by earlier reports by Arnborg (1984 cited in Erakhrumen et al, 2010) which indicated that as much as half of the timber harvested in the world is used as fuelwood for cooking and other heat applications, most of which are used in the developing countries (International Energy Agency, 2002 cited in Erakhrumen et al., 2010). Estimates show that fuelwood accounts for about $90 \%$ of the timber harvested in developing countries (Food and Agricultural Organisation, FAO, 2007 cited in Erakhrumen et al, 2010). Guo (2007) also found that charcoal producers obtain the wood free from the forest and farms. The ramifications from the use of the forests as common-property resource are borne by the entire society while benefits accrue to the individual user of the forest resource.

Emanating from the use of the forests as common-property resources and the excessive use of fuelwood as household cooking fuel, the Energy Commission (2010b) reveals that there is an imbalance between wood fuel consumption and yield in Ghana. The Commission predicts that the overdependence on wood fuel would increase its consumption levels to four times as much as the 2000 levels by 2020. Demand for wood fuel in Ghana in 2000 was about 14 million tons but projected to increase to between 38-46 million tons by 2012, and 54-66 million tons by 2020. The projected increase in wood fuel consumption is in tandem with the FAO's prediction of a continuous increase in charcoal consumption in SSA (FAO, 1999 cited in Erakhrumen et al, 2010). Ottu-Danquah (2010) found that the major charcoal producing areas in Ghana are showing physical signs of forest depletion because of over extraction from the forest without commensurate replacement. Songsore (2003) identifies commercial charcoal production in Africa as a major cause of ecological degradation. The Environmental Protection Agency (EPA, 2003) also reveals that denudation has occurred in large areas of the towns and villages in the savannah and transitional agro-climatic zones in the Brong Ahafo, Northern, Upper East and West regions of the country. Makhabane (2002) also revealed that large quantities of forest residues (about 
0.86 million tonnes in 2001) were destroyed as a result of charcoal production. Similarly, the Resource Watch Agenda (2010 cited in Lurumuah, 2011) opines that Ghana has lost more than 75\% of her 8.2 million hectares of forest cover due to the imbalance between extraction and replacement of forest resources.

From the foregoing, the authors argue that though charcoal will continue to supply the bulk of the country's cooking energy needs, its prospects in guaranteeing a sustainable energy access and household income is bleak. This argument is based upon the non-commensurate replacement of the forest resources after harvesting for charcoal production. Pabi and Morgan (2002) maintain that the Government of Ghana has become increasingly concerned about the need to preserve the country's wood fuel resources. What is required now is government and all other stakeholders' effort to protect the environment. Msuya et al. (2011) add that there is an urgent need to reduce pressure on the forests through the development and deployment of more environment-friendly alternative sources of energy for cooking in Tanzania. This premise is oblivious of the industry's role as a provider of livelihood to households. Athough commercial charcoal production has proven to be harmful to the environment, shutting down the industry is challenged by its role in employment creation and the provision of household income.

The purpose of this research was to identify the way forward towards sustainable supply of households' energy needs, and household incomes without compromising on environmental sustainability. The paper achieves this by analysing the issues that provide answers to the following questions:

- What are the effects of commercial charcoal production on household income?

- What are the environmental implications of commercial charcoal production methods on the forest of the region?

- What is the way forward towards sustainable development of commercial charcoal producing communities?

\section{The Research Districts}

The Wa East District is remotely located in the south eastern part of the Upper West Region of Ghana. The district shares boundaries with West Mamprusi to the northwest, West Gonja to southeast and Sissala East to the north. It has a landmass of about $1,078 \mathrm{~km}^{2}$, which lies between latitudes $9^{\circ} 55^{\prime} \mathrm{N}$ and $10^{\circ} 25^{\prime} \mathrm{N}$ and longitudes $1^{\circ} 10^{\prime} \mathrm{W}$ and $2^{\circ} 5^{\prime} \mathrm{W}$. The remoteness of the district relative to other districts in the region has deprived it of basic social and economic infrastructure and services (Wa East District Medium Term Development Plan, 2006-2009; unpublished).

The Sissala East District, located in the Upper West Region, shares a common border with Burkina Faso. To its east are the Kassena-Nankana and Builsa districts in the Upper East Region. The district shares boundary at the south-eastern portion with West Mamprusi District of the Northern Region. The district has a total land size of 4,744 square kilometres and represents $26 \%$ of the total landmass of the Upper West Region (Sissala East District Medium Term Development Plan, 2006-2009; unpublished).

The Sissala West District in the Upper West Region shares boundaries with the Jirapa Lambussie District to the west, Sissala East District to the east, Wa East District to the south and Burkina Faso to the north. The district's landmass of 411,289 square kilometres is about 25\% of the Upper West Region's landmass (Sissala West Medium Term Development Plan, 2006-2009; unpublished).

The three districts experience single maxima rainfall pattern usually from May-October by virtue of their location in the Guinea Savannah agro-climatic zone. This agro-climatic zone is characterised by isolated woodlands, short thick trees, shrubs and grasses. The common economic trees in the three districts are shea nut, baobab, kapok, dawadawa, acacia, neem and ebony. The single maxima rainfall pattern hinders all-year-round agriculture resulting into low household expenditure per capita of GH\& 166.00 per annum; the lowest in Ghana (Ghana Statistical Service, 2008). Commercial charcoal production is thus considered as a major source of household income in the three districts.

\section{Empirical Research Strategy}

Mixed methods of research were used to elicit, collate and interpret data to answer the research questions. Alatinga and Fielmua (2011) define the "mixed methods" of research as the combination of both quantitative and qualitative strategies to collect and analyse data. The strength of this strategy is that the weakness of one will be compensated for by using an alternative method (Bryman, 2008 cited in Alatinga and Fielmua (2011). 


\subsection{Sampling Procedure}

The target population was commercial charcoal producers and bulk buyers in the three research districts. A multi-stage sampling technique was used to select the units. The three districts, Sissala East, Sissala West and Wa West districts were purposively selected due to the dominance of the exploitation of their forest resources for commercial charcoal production. The districts thus supply the bulk of charcoal produced in the region. Commercial charcoal production which is associated with the Sissala ethnic group has been a traditional economic activity in the three districts.

A master list of the charcoal producers in the three districts was obtained from the Forestry Commission (FC). The master list detailed the names and addresses of the registered commercial charcoal producers operating in the three districts. With the lottery method, the charcoal producers were randomly selected from the list. The specific random sampling technique adopted was the lottery method operationalised by assigning numbers to the commercial charcoal producers on pieces of paper and placing them in a box. These numbers were then drawn one after the other, till the required number of charcoal producers was selected.

\subsection{Sample Size Determination}

The researchers adopted a mathematical model from Miller and Brewer (2003) to determine the sample sizes for each of the zones at $99 \%$ confidence level. The model is expressed below:

$n=\frac{N}{1+N(\propto)^{2}}$. Where $\mathrm{N}$ is the sample frame; $\mathrm{n}$ is the sample size and $\alpha$ is the confidence interval $(97 \%)$.

At a significant level of $99 \%$, the sample size for the research was 500 from a population of 526 commercial charcoal producers in the three districts.

\subsection{Sources and Methods of Data Collection}

The researchers used information from both secondary and primary sources to assess the economic and environmental effect of commercial charcoal production on community development in the Upper West Region. The secondary sources provided the theoretical and conceptual arguments for the conservation of forest resources for sustainable community development. The secondary data were collected through desk study of published and unpublished materials relevant for the subject under investigation.

The primary data were gathered through direct interviews using semi-structured questionnaires and interview guides with charcoal producers, commercial drivers, community leaders and environmental experts. Through direct interviews, 500 commercial charcoal producers (see Table 1), 10 truck transport operators, 10 donkey-drawn cart operators and 50 charcoal buyers were interviewed from three purposively selected districts within the Region. The purpose of interviewing the commercial charcoal producers, charcoal buyers and commercial transport operators was to unearth the economic dimensions of commercial charcoal production in the three districts. It was also to estimate the quantity of charcoal produced, sources of the raw materials for charcoal production and their ramifications for sustainable forest management.

Through key informant interviews and six focus group discussions guided by checklists, the District Assembly and the Forestry Commission of each district, and community leaders (Assembly Members and Traditional Authorities) of each research community were interviewed. The intent was to examine the effectiveness of forest conservation practices in the charcoal producing communities.

The researchers employed direct observation skills to identify the environmental consequences of commercial charcoal production. The outputs of the researchers' observations are the plates (pictures) of the production methods and the type of trees used for charcoal production.

\subsection{Data Analysis and Presentation}

Quantitative and qualitative data were gathered from the units (charcoal producers, buyers and transporters) through interviews using semi-structured questionnaires. The quantitative data collected with the semi-structured questionnaires were analysed using Census Processing System (CSPro) version 4.0 and Statistical Package for Social Science (SPSS) version 16 and expressed in the forms of arithmetic mean and range. Specifically, the monthly incomes of the actors, prices of charcoal and quantity of charcoal produced and sold in a month were analysed using the arithmetic mean and range methods.

For the hypothesis testing, the researchers employed the Mann-Whitney/Wilcoxon rank sum test to analyse the quantity of charcoal and by implication the incomes of the actors in the three study districts. A significance level of 0.01 was used for the test at a degree of freedom of 328 (the t-test statistic follows a t distribution with $195+135-2=328$ degree of freedom). 
The study was challenged by the lack of data on the tree population over the years at the micro level which could have been used as a basis for the estimation of the charcoal industry's role in deforestation in the three districts. Due to this challenge, the researchers analysed the environmental effects of the charcoal industry in the three districts largely from the perceptions of the actors and key informants expressed in comprehensive statements quoted from them. These comprehensive statements were then triangulated with expert views from the Forestry Commission and the Renewable Energy Units of the Energy Commission. The industry's contribution Tt environmental degradation was analysed by estimating the number of trees cut for charcoal production per month. This was done by first identifying the average number of trees used by a producer per one compete cycle of production. The result was then multiplied by the number of times the actor produced charcoal per month which was in turn multiplied by the number of charcoal producers in the three districts.

\section{Evolution of Charcoal Production in the Three Districts}

From a focus group discussion (FGD) and key informant interviews, the researchers noted that charcoal production in the area dated far back to the beginning of human civilisation. Participants at the FGD in the Sissala East district did indicate that charcoal production was a long standing and inter-generational activity in their communities. "Commercial charcoal production in our area has no definite start date. We were born into it".

It was also established that charcoal production in the districts was initially for domestic use, with dead logs or trees as the main raw materials. This did not have any major negative impacts on the vegetation since only dead logs or trees were used as the raw materials. Blench (2006) argues that the low population density of the Upper West Region which has permitted forest conservation is the major factor sustaining commercial charcoal production in the region. Participants at the FGD explained that the use of only dead logs or trees could not meet the high and ever-increasing demand for charcoal. Thus, the high and increasing demand for charcoal has resulted in the use of live trees as raw materials for charcoal production.

\section{Characteristics of Respondents}

The researchers identified that persons of different age and sex groups were engaged in commercial charcoal production in the three districts as presented in Table 2. However, the most dominant age groups were the 20-29 years, 30-39 years and 40-49 years all together accounting for $20.2 \%, 31.6 \%$ and $21.4 \%$, respectively.

The $20-49$ years age bracket accounted for $73 \%$ of the labour engaged in commercial charcoal production. The researchers observed that the 20-49 years age group dominated because of the tedious nature of commercial charcoal production which required a lot of energy. This claim is also underscored by the male dominance (accounting for 66\%) in commercial charcoal production. The charcoal producers cut and gather into heaps of logs and branches of trees (i.e. the main raw materials) and raise mounds to cover the heaps to produce the charcoal (see Figure 4).

All the 20 commercial drivers interviewed were males whose ages ranged from 37 to 48 years. They argued that "it takes a considerable number of years of driving to acquire the requisite licence to drive the trucks that are used for transporting charcoal. One may already be old by the time the licence is acquired". From the drivers' perspectives, none of them is a youth (referring to people whose ages range from 18 to 35 years) because of the cumbersome process of acquiring a licence to drive the heavy-duty trucks.

The researchers further identified that three ethnic groups were the major producers of charcoal in the three districts. Figure 1 indicates that the Sissala ethnic group was the most dominant (accounting for $64 \%$ ) relative to the Dagaabas (25\%) and Waales (11\%). The dominance of the Sissalas possibly explains the association of the production and sale of charcoal with the Sissala ethnic group.

\section{The Effects of Commercial Charcoal Production on Household Income}

The researchers examined the quantity of bags (maxi bags) of charcoal produced per producer per month and the subsequent income derived from its sale. The researchers also assessed the economic gains derived from the charcoal industry by the commercial drivers and charcoal buyers who bought the charcoal from the producers and sold to retailers in the urban areas.

\subsection{Commercial Charcoal Production and Household Income}

Charcoal production in the three districts was identified to be a major source of household income. Through one-on-one interviews with the 500 commercial charcoal producers, the researchers identified that the charcoal producers underwent an average of two cycles of production in a month. As indicated in Table 2, the average 
number of bags of charcoal (each maxi bag weighs an average of $60 \mathrm{~kg}$ ) produced per producer in the three districts was 20.3. The output, however, ranged from 20.1 to 20.5 bags per month.

The researchers used the t-test to ascertain the significance or otherwise of the differences in the producers' output (i.e. average number of bags of charcoal produced). The researchers tested the hypothesis that the three means do not differ significantly as expressed below:

$\mathrm{H}_{\mathrm{o}}: \mathrm{x}_{1}=\mathrm{x}_{2} \quad \mathrm{H}_{1}: \mathrm{x}_{1} \neq \mathrm{x}_{2}$

\section{Wa West}

Mean $\left(\mathrm{x}_{1}\right)=20.45$

Standard deviation $=0.99$

Sample $=195$

\section{Sissala East}

Mean $\left(\mathrm{x}_{2}\right)=20.27$

\section{Sissala West}

Mean $\left(\mathrm{x}_{3}\right)=20.36$

$$
\text { Standard deviation }=0.82 \quad \text { Standard Deviation }=1.06
$$

$$
\text { Sample }=135 \quad \text { Sample }=170
$$

$$
Z=\frac{x_{1}-x_{2}}{S E}
$$

Where

$$
\begin{aligned}
& \mathrm{x}_{1}=\text { Mean number of bags }- \text { Wa West District } \\
& \mathrm{x}_{2}=\text { Mean number of bags }- \text { Sissala East District } \\
& \mathrm{SE}=\text { standard error expressed as: }
\end{aligned}
$$

$$
\begin{aligned}
& \sqrt{\frac{S_{P}^{2}}{n_{A}}+\frac{S_{P}^{2}}{n_{B}}} \\
& \left.S_{p}=\sqrt{\frac{\left(n_{A}-1\right) S_{A}^{2}}{n_{A}+n_{B}-2}}\right\} \text { pool variance } \\
& S_{P}=\frac{\left(194 * 0.99^{2}\right)+\left(134 * 0.82^{2}\right)}{195+135-2}=0.90 \\
& S E=\sqrt{\frac{S_{P}^{2}}{n_{A}}+\frac{S_{P}^{2}}{n_{B}}} \\
& =\sqrt{\frac{0.90}{195}+\frac{0.90}{135}} \\
& =\sqrt{0.011282} \\
& \text { S.E. }=0.1062
\end{aligned}
$$

Then $\frac{x 1-x 2}{S E}$

$$
\begin{gathered}
\text { S.E. }=\frac{20.45-20.27}{0.1062} \\
\text { S.E. }=1.69
\end{gathered}
$$

Degree of freedom $=195+135-2=328$

$t_{\infty} 0.01=2.576$.

Since the calculated value (1.69) is less than the critical value of $t$ at $1 \%$ error margin (2.576), the null hypothesis (that there was no significant difference between the two means $x_{1}=x_{2}$ ) is accepted. The researchers tested the level of significance or otherwise of the difference between the Wa West district's mean $\left(\mathrm{x}_{1}\right)$ and Sissala West district's mean $\left(\mathrm{x}_{3}\right)$.

$$
\begin{aligned}
\mathrm{H}_{0}: \mathrm{x}_{1}=\mathrm{x}_{3} \quad \mathrm{H}_{1}: \mathrm{x}_{1} \neq \mathrm{x}_{3} & \\
& =\frac{\left(194 * 0.99^{2}\right)+\left(169 * 1.06^{2}\right)}{195+170-2} \\
& =1.05 \\
& =\sqrt{\frac{1.05}{195}+\frac{1.05}{170}} \\
& =\sqrt{0.0088} \\
& 0.108
\end{aligned}
$$


Thus:

$$
\begin{aligned}
& =\frac{20.45-20.36}{0.108} \\
& =0.83
\end{aligned}
$$

Degree of freedom $=195+135-2=328$

t\$o $0.01=2.576$.

Since the calculated value $(0.83)$ is less than the critical value of $t$ at $1 \%$ error margin (2.576), the null hypothesis (that there was no significant difference between the two means $\mathrm{x}_{1}=\mathrm{x}_{3}$ ) was accepted. In sum, the observed differences among the three means (i.e. the average number of bags of charcoal produced per district) might be the results of sampling error. Hence, $\mathrm{x}_{1}=\mathrm{x}_{2}=\mathrm{x}_{3}$.

The researchers further identified the price of a maxi bag of charcoal to be GHф10. Premised on this, the researchers estimated the average revenue accrued to the commercial charcoal producing households to be about GHф200 per month (and an annual revenue of about GHф2 400, i.e. GHф200*12). A comparative analysis of the monthly incomes of the commercial charcoal producers with the regional average income revealed that the commercial charcoal producers earned higher incomes than the average person in the Upper West Region. The commercial charcoal producers earned about 296\% higher than the region's mean annual household revenue of GHф606 (Ghana Statistical Service, 2008: 107). Furthermore, the charcoal producers annual revenue of GHф2 400 was observed to be about $97.2 \%$ higher than the national average revenue of GH $₫ 217$ (Ghana Statistical Service, 2008: 107).

\subsection{Commercial Charcoal Production and Incomes of Other Stakeholders in the Charcoal Industry}

The other stakeholders the researchers considered were drivers who transported the charcoal from the rural producing areas to the urban consuming areas; and the buyers (middlemen) who procured the charcoal from the producers for onward sale to charcoal retailers in the urban areas. The researchers identified two categories of drivers namely operators of trucks who conveyed the charcoal in bulk from the rural producing areas to the urban consuming centres, and the donkey-drawn-cart users who transported the charcoal from the bush to the communities to be loaded onto the trucks (see Figure 2).

Donkey-cart-operators charged a mean price of GHф1 for every one maxi bag of charcoal transported. The researcher observed that the donkey carts could take an average of six maxi bags usually for a distance of five kilometres. The donkey-drawn-cart operators could undertake two trips during the rainy season and four trips during the dry season all in a week. Thus, the donkey-drawn-cart operators earned amounts ranging from GH $24-48$ per month. The donkey-drawn-cart operators' roles were significant due to the fact that accessibility to some of the charcoal producing points was constrained by the poor nature of roads.

The researchers identified that the donkey-drawn-cart operators did not incur operational cost since the donkeys are fed with feed and water from the forest and streams, respectively. In a FGD with eight donkey cart operators, the researchers identified that the charcoal industry provided a good source of income to complement household earnings.

The bulk buyers also bought and sold an average of 140.5 maxi bags of charcoal in a month as presented in Table 4. The farm gate price of the charcoal was GHф10 per maxi bag. The buyers then hired KIA trucks (which could transport an average of 150 bags at a time) at costs ranging from GH\&800-1 000 per trip. The other type of truck used to convey charcoal was "Axiom" (heavy duty trucks) whose carrying capacity was about two times (250-300 maxi bags) that of the KIA trucks. The Axiom vehicle operators charged between GHф1 000-1500 per trip.

In a cross-tabulation of quantities of charcoal bought, their destinations and type of vehicles used for conveyance, the researchers identified that the farthest destination for all the charcoal buyers who bought less than 50 maxi bags (i.e. 10\% of the charcoal buyers as indicated in Tables 4 and 5) was Wa and its environs. KIA vehicles were the only means of transport used by these buyers. Furthermore, all the buyers who bought between 50 - 99 maxi bags, and $80 \%$ of those who transported between 100 - 149 maxi bags of charcoal ended at Sunyani and its environs (including Techiman and Berekum all in the Brong Ahafo Region). The remaining 20\% ended in Kumasi and its environs. KIA trucks were the only means of transport.

The researchers also identified that all the buyers who bought between 150 - 199, and 200 - 249 maxi bags of charcoal ended in Kumasi and its environs. Axiom trucks were identified as the means of transporting these maxi bags of charcoal to their destinations. Furthermore, all the buyers who transported more than 250 maxi bags of 
charcoal ended in Accra and its environs. Axiom trucks were also identified as the major means of transporting these large quantities of charcoal.

The research revealed that the charcoal buyers hired the vehicles they used to transport the charcoal. Whilst KIA users hired at rates ranging from GH\&800 - 1000 per trip, Axiom users hired theirs at rates ranging from GH $\not 1$ 000-1 500. The charcoal buyers also paid taxes to the three District Assemblies (Wa West District Assembly, Sissala East District Assembly and Sissala West District Assembly) at GH $\notin 1$ per maxi bag. The researchers estimated the monthly revenue accrued to the Assemblies through taxes to be about GHф203.36 (i.e. 20.36 maxi bags by GH $\not 1)$. Hence, the charcoal producers contributed about $\mathrm{GH} \notin 2440.32$ to the Assemblies' internally generated revenue (IGR). This finding complements Mason's (2009) finding that local government agencies derive substantial revenue from charcoal tax. A cross-tabulation of transport charges and destination revealed that charcoal buyers whose destinations were within the Upper West Region paid an average of GH $\phi 800$ per trip which was often shared among an average of four buyers. Furthermore, the KIA drivers whose destinations were Sunyani and its environs charged GH $\phi 1000$ per trip. Axiom truck drivers who transported the commodities to Kumasi and its environs (i.e. the Ashanti Region) charged an average of GH $\not 1000$ per trip. Finally, the Axiom drivers whose destinations was the Greater Accra Region charged about GH\& 1500 per trip.

Following the identification of the transport charges, taxes paid to the Assemblies and the farm gate price of the charcoal traded in, the researchers estimated the monthly earnings of the buyers as indicated in Table 5. The researchers identified that charcoal buyers whose destinations were in Wa and its environs (who traded in less than 50 maxi bags per trip) sold a bag of charcoal for GH $\phi 20$, implying a total revenue of GH $\phi 490$ per trip and a total investment cost of GH $₫ 469.50$. A KIA truck operator charged GH $\notin 800$ to Wa and its environs and this cost was often shared among an average of four buyers. Thus each buyer would pay about GH $\varnothing 200$ per trip.

The charcoal buyers whose destinations were in the Brong Ahafo Region (i.e. Sunyani and its environs) who traded in quantities of charcoal ranging from 50 - 99 maxi bags per trip sold a bag of charcoal for GH $\phi 20$; implying a total revenue of GH $\not 1490$ per trip with a cost price of GH $\not 1$ 319.50. A KIA truck operator charged GH $\not 1000$ to Sunyani and its environs which was also shared between an average of two buyers. Each buyer thus paid about GH $₫ 500$ per trip. After wholesaling the charcoal to retailers, the buyers earned an average of GH $\phi 170.50$ per trip (see Table 5). The second group of charcoal buyers whose destinations was the Brong Ahafo Region (i.e. $80 \%$ of the buyers who bought between 100-149 maxi bags) earned an average of GH $\phi 120.5$ per trip.

The buyers who transported their commodities to Kumasi earned amounts ranging from GH $\not 120.50-1020.50$ per trip (See Table 5). The highest earners were the buyers who sold the charcoal in the Greater Accra Region. This group of buyers earned about GH\&2 343.00 per trip. The explanation was that the real transport cost reduced as the number of bags purchased increased. This was because the drivers charged fixed amounts per a destination irrespective of the quantity of charcoal transported. A buyer could therefore beat down the transport cost by increasing the number of bags of charcoal he transported.

A probe revealed that the buyers whose destinations were in Wa and its environs undertook an average of four trips in a month as indicated in Table 6. The number of monthly trips, however, decreased as the buyers' destinations (in terms of distance travelled) increased. In sum, charcoal production has not only been beneficial to the producers but also to buyers and transport operators. Through the tax component, District Assemblies of producing districts have also benefitted immensely from the charcoal industry.

The researchers identified that due to its quality, charcoal produced in the Upper West Region was the most preferred in Ghana. A FGD with producers identified that the type of trees, notably the shea trees, used for charcoal production was the reason for this quality and the subsequent preference the consumers had for the charcoal produced from the Upper West Region.

\section{The Effects of Commercial Charcoal Production on the Environment}

In this section of the paper, the researchers examined the type of wood used as raw materials for commercial charcoal production and the charcoal production technology for the examination of the possible effects on the environment.

\subsection{Wood Sources for Commercial Charcoal Production}

The charcoal producers obtained the trees and logs they used for charcoal production from the natural forest. The researchers identified that about $88 \%$ of the charcoal producers use live trees taken from the natural forest as indicated in Figure 3. A probe revealed that charcoal producers used live trees because the dead ones were 
almost depleted from the natural forest. Furthermore, the live trees are easier to fell and process than the dead ones.

The researchers observed that the harvesters of the trees cut about 40 centimetres above the ground level with tools such as axes, cutlasses and at times chainsaws with the hope of enabling the forest to rejuvenate. This method of harvesting from the natural forest inhibits replenishment commensurate with the rate of extraction.

The survey revealed that about $48 \%$ and $22 \%$ of the charcoal producers have strong preferences for shea trees and mahogany for charcoal production. This corresponds with EPA's survey in 40 communities in the Upper West Region which identified that $80 \%$ of charcoal produced in the Upper West Region came from shea trees (Friends of the Earth-Ghana, 2002). The remaining 30\% were indifferent and used any tree they chanced upon in their search for raw materials for commercial charcoal production. The shea tree, which has numerous economic benefits but have between 20 and 25 years of gestation are under threat of depletion from the research communities.

\subsection{Method of Charcoal Production}

All the charcoal producers in the three research districts used the traditional/earth mound method of charcoal production as presented in Figure 4. The researchers identified that about $65 \%$ of the charcoal producers were aware of the Energy Commission's improved kilns, but maintained that they were expensive. This triangulates the Energy Commission's findings that commercial charcoal producers consider its improved kilns as expensive (Ottu-Danquah, 2010). The remaining 35\% do not know any other technology apart from the traditional earth-mound kilns. The charcoal production process began with the selection of the required trees by species and by sizes. Without the need for permits, the identified trees are harvested from the natural forest explained earlier as common-property resource.

Secondly, the harvested woods were then sawn (usually $1 \mathrm{~m}$ long) and sorted by diameter and heaped next to the burning sites (as indicated earlier in Figure 3). The sorted wood was then stacked into a dug-out earth pit or heaped on a relatively flat plain up to a reasonable height and covered with a layer of grass and sand as depicted in Figure 4. The heaped logs were then covered with sand leaving two very tiny openings for fire to be lit and smoke to exit.

Finally, the covered heap of wood was then lit from the opening. The carbonisation process would be closely monitored both day and night for about 10-15 days, depending on the size and moisture content of the wood. Gradually the logs burned into the required charcoal. The charcoal was then collected into bags and sold either to charcoal merchants or individually along the roadside.

The earth mound method of charcoal production inflicts damage to the vegetation. As observed from the major charcoal producing sites in the research communities, this process has several weaknesses. In a FGD, charcoal producers admitted that the charcoal producing process often caused bushfires. The researchers considered these as having implications for the sustenance of flora and fauna in the communities. The researchers further observed that the vegetations around the numerous mound areas were lost. An expert view elicited from the Renewable Energy Section of the Energy Commission revealed that the traditional method of charcoal production is inefficient, unhealthy and unfriendly to the environment (Ottu-Danquah, 2010).

\subsection{Quantity of Trees Used for Charcoal Production and its Effects on the Environment}

The researchers identified that a combination of logs and shrubs were used for commercial charcoal production in the three districts. The quantity of raw materials used for charcoal production was contingent upon the type of trees and logs used and their sizes. In a FGD, the commercial charcoal producers used matured shea and mahogany trees, to describe the quantity of trees and logs used for one cycle of charcoal production. The shea and mahogany tree species were used as the points of reference because of the preference the commercial charcoal producers had for these trees and their frequency of use as raw materials for charcoal production. A typical question asked was "considering your output per production, how many shea trees or mahogany trees could yield that output". Thus the analyses on the quantity of trees used for charcoal production per annum therefore do not imply that the commercial charcoal producers used only one type of tree for charcoal production.

The researchers established through the FGD that the quantity of logs and shrubs used for one complete cycle of charcoal production was equivalent to two matured shea trees (i.e. using the shea tree as the measuring scale). A sample of shea trees selected from the three districts measured between $10-44$ centimetres in diameter at breast height and 15-20 metres high (see Figure 5). This implies that a charcoal producer could use an average of four trees in a month (i.e. two matured trees fitting the description of a matured shea tree multiplied by the two cycles 
of charcoal production in a month). By implication, the sample population could use about 24000 matured trees in a year for charcoal production. The researchers noted that the commercial charcoal producers were able to harvest the trees and logs with the aid of chainsaws. The known gestation period for the shea tree, however, was 10-15 years and this implies that the natural rejuvenation process would not be able to catch up with the rate of extraction. This finding supports the claim that commercial charcoal production causes severe environmental degradation in terms of deforestation and denudation (Friends of the Earth, 2002; Makhabane, 2002; Msuya et al., 2011; Ottu-Danquah, 2010; Songsore, 2003).

Another preferred tree species for charcoal producers was mahogany and the commercial charcoal producers were thus able to use it as a measuring rod to establish the quantity of trees and logs used for charcoal production. A sample of the scarce mahogany trees found in the study area measured about 45 metres (150 feet) in height and 1.8 metres ( 6 feet) in diameter. The group discussion with the commercial charcoal producers also established that one matured mahogany tree could be used for about six streams of production. This implies that a charcoal producer harvested about four trees that were similar to the description given to the mahogany, for charcoal production in a year. By implication, about 2000 trees could be used for charcoal production in a year. Relating this to the gestation period of about 50-100 years also provided an explanation for the high rate of vegetation loss in the charcoal producing communities. Furthermore, the phenomenon is a good explanation for why the mahogany trees were scarce in the study area.

With the use of chain-saws, the charcoal producers were able to harvest their preferred trees in about one hour per shea tree and four hours per mahogany tree (see Figure 3). Hitherto, the charcoal producers were using axe to manually harvest the trees. It took them an average of three days to prepare their logs for burning. Thus, the chain-saws have quickened tree harvesting which has in turn catalysed the rate of deforestation in the region as evident in Figure 3.

Interventions by Charcoal producers to sustain the forest are limited in the area. The researcher identified that about $88 \%$ of charcoal producers believed that trees regenerate naturally after harvesting. As a result of this, they did not see the need to make any conscious attempts to sustain the tree population through replanting after cutting them. The only forest sustainability measure adopted by the people is agro-forestry. However, the particular tree species used for this intervention is the mango plants which unfortunately were not used for charcoal production. The researchers see this situation as a threat to the natural forest as trees are being exploited without commensurate replacement.

\section{Summary, Recommendations and Conclusion}

The paper sought to examine the effects of commercial charcoal production on the economic standings of stakeholders in the Upper West Region of Ghana. The intent was to advocate for the sustenance of the charcoal industry instead of prohibiting the production and use of charcoal as recommended by Msuya et al., (2011). The researchers sampled and directly interviewed 500 commercial charcoal producers, 10 truck transport operators, 10 donkey-drawn-cart operators and 50 charcoal buyers. The researchers further interviewed community leaders and experts from the Energy Commission and Forestry Commission for expert views on the effects of commercial charcoal production on the environment.

The researchers identified that commercial charcoal production in the three districts had been sustained because the industry was a major source of livelihood not only to producers but buyers and transport operators as well. The researchers identified that commercial charcoal producers earned a monthly income of GH $₫ 200$ from charcoal production and sale. The monthly earnings of the charcoal buyers ranged from GH $\not 82-2343$. Donkey-drawn cart operators also earned an average of $\mathrm{GH} \phi 48$ per month.

Despite its economic importance, the industry posed serious environmental consequences which were borne by the entire society and not only by the operators within the industry (as explained in "the tragedy of the commons"). The destruction of the forest has the tendency to compound the already increasing temperatures and unfavourable rainfall regimes as argued by Friends of the Earth (2002) and Msuya et al., (2011). The method of charcoal production (earth-mound kilns) and the process used (direct extraction of live trees from the forest without commensurate replacement) were observed as causes of deforestation. The forests were unable to replenish itself because of excessive extraction for charcoal production. The researchers identified that about 24 000 trees of an average size of between 10 - 44 centimetres in diameter at breast height and 15-20 metres high were converted to charcoal in the charcoal producing communities. About 2000 trees of mean size of 45 metres in height and 1.8 metre in diameter were used for charcoal production in the three districts. The destruction of the vegetation threatens the sources of livelihoods for many in the three research districts if it is not addressed. 
Underpinned by the industry's economic importance, the researchers recommend that the Government of Ghana should subsidise the cost of the improved kilns to enable the charcoal producers obtain them to cut down wastage. The subsidies could reduce the charcoal producers' reluctance to invest money in charcoal production. The Energy Commission should also undertake intensive education to enable commercial charcoal producers get used to the improved kilns. The adoption of the improved kilns could introduce efficiency into commercial charcoal production and slow down the rate of deforestation and curtail its multiplier effects within and outside the districts.

Furthermore, the forest should be replenished through agro-forestry carefully guided by research to identify suitable trees with shorter gestation periods. The Council for Scientific and Industrial Research (CSIR), Forest Research Institute and Ministry of Food and Agriculture (MoFA) should collaborate to identify economic trees with shorter gestation periods to guarantee sustainable supply. A breakthrough in research could enhance woodlot establishment which could be accessible to all the commercial charcoal producers. The potential for woodlot cultivation is that various governmental and non-governmental organisations in the region have begun offering assistance to women groups to cultivate woodlots as a means to curtailing the problems of deforestation arising out of the increased demand for wood fuel (Guo, 2007). By the use of net present value (NPV) and internal rate of returns (IRR), Guo (2007) identified that the woodlots were profitable ventures which could be explored further to supply the raw material needs of the commercial charcoal producers in Ghana quest for environmental sustainability.

\section{References}

Alatinga, K. A., \& Fielmua, N. (2011). The impact of mutual health insurance scheme on access and quality of health care in Northern Ghana: The case of Kassena-Nankana east scheme. Journal of Sustainable Development, 4 (5), 125-138. http://dx.doi.org/10.5539/jsd.v4n5p125

Blench, R. (2006). Background conditions in upper west region, Northern Ghana, 2005, Interim evaluation of UWADEP, Draft Working [Online] paper. Available: http:/www.rogerblench.info/Development/Ghana/IFAD/UWADEP/Blench\%20UWR\%20working\%20paper.pdf (October 29, 2011)

Energy Commission. (2010a). Ghana energy statistics 2000-2008. [Online] Available : http://www.energycom.gov.gh/pages/docs/Ghana\%20Statistics\%202000_2008.pdf (February 8, 2010)

Energy Commission. (2010b). Bio-energy draft policy for Ghana, Accra. [Online] Available : http://new.energycom.gov.gh/downloads/BIOENERGY.pdf (January 19, 2010)

Environmental Protection Agency. (2003). National action programme to combat drought and desertification. Accra, Ghana, Environmental Protection Agency.

Environmental Protection Agency. (2005). Ghana State of the Environment Report 2004. Accra, Ghana: Environmental Protection Agency.

Erakhrumen, A. A. (2010). Implications of Global Economic Recession/Volatility in Petroleum Products' Price, Demand, and Supply on Fuelwood Consumption and Mangrove Forests' Survival in the Niger-Delta Region. In Popoola, L., Idumah, F. O., Adekunle, V. A. J., \& Azeez, I. O. (Eds.) The Global Economic Crisis and Sustainable Renewable Natural Resources Management. Volume 2 of the Proceedings of the $33^{\text {rd }}$ Annual Conference of the Forestry Association of Nigeria held in Benin City, Edo State, Nigeria, from the 25th to 29th of October, 2010, pp. 136-147.

Erakhrumen, A. A., Ogunsanwo, O. Y., \& Ajewole, O. I. (2010). “Assessment of Some Other Traditional Uses of Accepted Agro-forestry fuelwood Species in Akinyele and Ido Local Government Areas, Oyo State, Nigeria". International Journal of Social Forestry (IJSF), 3(1), 49-65. Accessed on January 16, 2012 from http://www.ijsf.org/dat/art/vol03/ijsf_vol3_no1_04_erakhrument_agroforestry_fuelwood_nigeria.pdf

Friends of the Earth, Ghana. (2002). More Trees Destroyed by Charcoal Producers. FOELINE. Accra, Ghana: Friends of the Earth - Ghana.

Ghana Statistical Service. (2005). Population Data Analysis Report; Socio-economic and Demographic Trends, Volume 1, Accra, Ghana Statistical Service.

Ghana Statistical Service. (2008). Ghana Living Standards Survey Report, the Fifth Round (GLSS 5), Accra, Ghana Statistical Service.

Ghatak, S. (2005). Introduction to Development Economics, Third Edition, Taylor and Francis e-Library, 2005. 
Government of Ghana. (2003). Ghana Poverty Reduction Strategy (GPRS 1) 2002-2004, an Agenda for Growth and Prosperity. Accra, Ghana, National Development Planning Commission.

Guo, E. (2007). Potential of woodlot establishment in meeting the practical and strategic gender needs of women in the upper west region of Ghana. Studies in Gender and Development in Africa. 1, 21-42.

Inkoom, D. K. B., \& Nanguo, C. Z. (2011). Utilisation of irrigation facilities towards poverty reduction. Journal of Sustainable Development in Africa, 13 (2), 335-351.

Kituyi, E. (2002). Towards Sustainable Charcoal Production and Use: a Systems Approach. Proceedings of a Regional Workshop on Woodfuel Policy and Legislation in Eastern and Southern Africa. RELMA, Nairobi, Kenya.

Lurumuah, S. (2011). The Economic and Environmental Effects of Commercial Charcoal Production in the Upper West Region of Ghana, a thesis submitted to the School of Graduate Studies, Kwame Nkrumah University of Science and Technology Kumasi in partial fulfilment of the award of Master of Science in Development Policy and Planning.

Makhabane, T. (2002). Gender and Sustainable Energy Issues in Africa: Perspectives for the World Summit on Sustainable Development, Regional Paper prepared for the WSSD, ENERGIA Network. [Online] Available: www.energia.org/pubs/index.asp (July 25, 2010)

Mason, J. J. (2009). Charcoal Production in Ghana. Building a Sustainable Model based on Community Management and Payments for Ecosystem Services. [Online] Available: www.katoombagroup.org/.../NCRCsustainablecharcoalSept08.pdf (January 20, 2012)

Miller R. L., \& Brewer, J. D. (2003). A-Z of Social Research - Dictionary of Key Social Science, Sage Publications, London.

Msuya, N., Masanja, E., \& Temu, A. K. (2011). Environmental burden of charcoal production and use in dar es salaam, tanzania. Journal of Environmental Protection, 2, 1364-1369. http://dx.doi.org/10.4236/jep.2011.210158

Mwampamba, T. H. (2007). Has the woodfuel crisis returned? Urban charcoal consumption in Tanzania and its implications to present and future forest availability. Elsevier Energy Policy, 35 (4), 221-234. http://dx.doi.org/10.4236/jep.2011.210158

Otu-Danquah, K. A. (2010). Current Status of Charcoal Demand and Supply, and Initiatives on Improved Cook-Stoves. A presentation made during a kickoff meeting for TEC/ESMAP survey on the energy access and productive uses for the urban poor, held in the SSNIT Guest House Conference Room, Accra on 11/08/2010.

Pabi, O., \& Morgan, E. A. (2002). Land-cover Change in the Northern Forest-Savannah Transition in Ghana', Commissioned Technical Report for the NRSP R7957 Project. [Online] Available: www.nrsp.org/pubs/index.rsp (November 20, 2010)

Songsore, J. (2003). Regional Development in Ghana: The Reality and the Theory. Accra, Ghana: Woeli Publishing Services.

\section{Notes}

Ghana Cedis most often expressed as GH\& and Ghana Pesewas (Gp) are the official currencies used in Ghana.

Sissala is an ethnic group found in the Upper West Region of Ghana. This group has traditionally been linked to commercial charcoal production more than any other ethnic group in Ghana.

Wa is the Upper West regional capital.

Sunyani is the Brong Ahafo Regional capital which is about $315 \mathrm{~km}$ away from the charcoal producing areas

Techiman is the capital of Techiman Municipality. Techiman is about $330 \mathrm{~km}$ away from the charcoal producing communities

Berekum is the capital of Berekum Municipality. Berekum is about $390 \mathrm{~km}$ away from the charcoal producing communities.

Accra: The national capital and the most populous city in Ghana. The estimated distance between the charcoal producing communities and Accra is about $570 \mathrm{~km}$.

Quality: means they take a longer time to burn in a cooking stove. The charcoal is not difficult to light and once lit it burns without fanning.

The selling price of GHф $₫ 20$ was multiplied by the average quantity of charcoal traded in (i.e. 24.5 bags). 
The selling price of GH $\varnothing 20$ was multiplied by the average quantity of charcoal traded in (i.e. 74.5 bags).

Total transport charges were cost-shared. Thus, the total transport charge was divided by the number of buyers who hired the same truck per trip to Wa and its environs.

Due to the large quantities of charcoal (200-249 maxi bags), the third group of buyers who transport their commodities to Kumasi do that once every month.

Table 1. Number of commercial charcoal producers interviewed, by district

\begin{tabular}{lcccc}
\hline District & $\begin{array}{c}\text { Number of } \\
\text { Communities }\end{array}$ & $\begin{array}{c}\text { Certified Commercial } \\
\text { Charcoal Producers }\end{array}$ & Sample Size & $\begin{array}{c}\text { Questionnaires } \\
\text { Administered }\end{array}$ \\
\hline Wa East & 17 & 203 & 195 & 195 \\
Sissala East & 16 & 144 & 135 & 135 \\
Sissala West & 15 & 179 & 170 & 170 \\
Total & 48 & 526 & 500 & 500 \\
\hline
\end{tabular}

Source: Field Survey, September, 2010

Table 2. Age distribution of commercial charcoal producers

\begin{tabular}{ccccccccc}
\hline \multirow{2}{*}{ Age group } & \multicolumn{2}{c}{ Wa West } & \multicolumn{2}{c}{ Sissala East } & \multicolumn{2}{c}{ Sissala West } & \multirow{2}{*}{ Total } & \multirow{2}{*}{$\%$} \\
\cline { 2 - 7 } & Number & $\%$ & Number & $\%$ & Number & $\%$ & & \\
\hline $10-19$ & 8 & 1.6 & 11 & 2.2 & 18 & 3.6 & 37 & 7.4 \\
$20-29$ & 36 & 7.2 & 30 & 6 & 35 & 7 & 101 & 20.2 \\
$30-39$ & 71 & 14.2 & 40 & 8 & 47 & 9.4 & 158 & 31.6 \\
$40-49$ & 43 & 8.6 & 28 & 5.6 & 36 & 7.2 & 107 & 21.4 \\
$50-59$ & 30 & 6 & 20 & 4 & 30 & 6 & 80 & 16 \\
60 and & 7 & 1.4 & 6 & 1.2 & 4 & 0.8 & 17 & 3.4 \\
above & & & & & & & & \\
Total & 195 & 39 & 135 & 27 & 170 & 34 & 500 & 100 \\
\hline
\end{tabular}

Source: Field Survey, September, 2010

Table 3. Quantity of charcoal produced per month

\begin{tabular}{|c|c|c|c|c|c|c|c|c|}
\hline \multirow{2}{*}{$\begin{array}{l}\text { Quantity (in } \\
\text { maxi bags) }\end{array}$} & \multicolumn{2}{|c|}{ Wa West } & \multicolumn{2}{|c|}{ Sissala East } & \multicolumn{2}{|c|}{ Sissala West } & \multirow[t]{2}{*}{ Total } & \multirow[t]{2}{*}{$\%$} \\
\hline & Number & $\%$ & Number & $\%$ & Number & $\%$ & & \\
\hline 18 & 12 & 2.4 & 9 & 1.8 & 6 & 1.2 & 27 & 5.4 \\
\hline 19 & 17 & 3.4 & 12 & 2.4 & 28 & 5.6 & 57 & 11.4 \\
\hline 20 & 95 & 19 & 71 & 14.2 & 79 & 15.8 & 245 & 49 \\
\hline 21 & 31 & 6.2 & 25 & 5 & 29 & 5.8 & 85 & 17 \\
\hline 22 & 22 & 4.4 & 12 & 2.4 & 13 & 2.6 & 47 & 9.4 \\
\hline 23 & 18 & 3.6 & 6 & 1.2 & 15 & 3 & 39 & 7.8 \\
\hline Total & 195 & 39 & 135 & 27 & 170 & 34 & 500 & 100 \\
\hline Average & \multicolumn{2}{|c|}{20.45 bags } & \multicolumn{2}{|c|}{20.27 bags } & \multicolumn{2}{|c|}{20.35 bags } & \multicolumn{2}{|c|}{20.36 bags } \\
\hline
\end{tabular}

Source: Field Survey, September, 2010 
Table 4. Quantity of charcoal (in maxi bags) bought by buyers (per month)

\begin{tabular}{ccc}
\hline Quantity & Number of Buyers & Percentage \\
\hline Below 50 & 5 & 10 \\
$50-99$ & 11 & 22 \\
$100-149$ & 10 & 20 \\
$150-199$ & 14 & 28 \\
$200-249$ & 6 & 12 \\
250 and above & 4 & 8 \\
Total & 50 & 100 \\
\hline
\end{tabular}

Source: Field Survey, September, 2010

Table 5. Total expenditure and revenue per trip

\begin{tabular}{|c|c|c|c|c|c|c|c|c|}
\hline Destination & $\begin{array}{l}\text { Number } \\
\text { of buyers }\end{array}$ & $\begin{array}{c}\text { Average } \\
\text { quantity } \\
\text { purchased } \\
\text { (maxi bags) }\end{array}$ & $\begin{array}{l}\text { Total } \\
\text { Farm } \\
\text { Gate } \\
\text { Cost }\end{array}$ & $\begin{array}{l}\text { Transport } \\
\text { Charges }\end{array}$ & $\begin{array}{c}\text { Tax } \\
\text { Payment to } \\
\text { the } \\
\text { Assembly }\end{array}$ & Total Cost & $\begin{array}{c}\text { Total } \\
\text { Revenue }\end{array}$ & $\begin{array}{c}\text { Net } \\
\text { Earnings }\end{array}$ \\
\hline & & A & $\begin{array}{c}\mathrm{B}= \\
\mathrm{GH} \phi 10 \\
* \mathrm{~A}\end{array}$ & $\mathrm{C}$ & $\begin{array}{c}\mathrm{D}=\mathrm{GH} \phi 1 \\
\text { per maxi } \\
\text { bag }\end{array}$ & $\begin{array}{c}\mathrm{E}=\mathrm{B}+\mathrm{C} \\
+\mathrm{D}\end{array}$ & $\mathrm{F}$ & $\begin{aligned} G= & F-(E \\
& -D\end{aligned}$ \\
\hline $\begin{array}{l}\text { Wa and its } \\
\text { environs }\end{array}$ & 5 & 24.5 & 245 & 200 & 24.5 & 469.5 & 490 & 20.5 \\
\hline $\begin{array}{l}\text { Sunyani and } \\
\text { its environs } \\
\text { (first group) }\end{array}$ & 11 & 74.5 & 745 & 500 & 74.5 & 1319.50 & 1490 & 170.5 \\
\hline $\begin{array}{l}\text { Sunyani and } \\
\text { its environs } \\
\text { (second } \\
\text { group) }\end{array}$ & 8 & 124.5 & 1245 & 1000 & 124.5 & 2369.50 & 2490 & 120.50 \\
\hline $\begin{array}{l}\text { Kumasi and } \\
\text { its environs } \\
\text { (first group) }\end{array}$ & 2 & 124.5 & 1245 & 1000 & 124.5 & 2369.50 & 2490 & 120.50 \\
\hline $\begin{array}{l}\text { Kumasi and } \\
\text { its environs } \\
\text { (second } \\
\text { group) }\end{array}$ & 14 & 174.5 & 1745 & 1000 & 174.5 & 2919.50 & 3490 & 570.50 \\
\hline $\begin{array}{l}\text { Kumasi and } \\
\text { its environs } \\
\text { (third group }\end{array}$ & 6 & 224.5 & 2245 & 1000 & 224.5 & 3469.50 & 4490 & 1020.50 \\
\hline $\begin{array}{c}\text { Accra and its } \\
\text { environs }\end{array}$ & 4 & 274.5 & 2745 & 1500 & 274.5 & 4519.50 & 6862.50 & 2343.00 \\
\hline
\end{tabular}

Source: Authors' construct with data from the field survey, September, 2010

Table 6. Monthly earnings of the charcoal buyers

\begin{tabular}{cccc}
\hline Destination & Number of Trips (per Month) & Net Earnings per Trip & Monthly Earnings \\
\hline $\begin{array}{c}\text { Wa and its environs } \\
\begin{array}{c}\text { Sunyani and its environs (first } \\
\text { group) }\end{array}\end{array}$ & 4 & 20.50 & 82.00 \\
$\begin{array}{c}\text { Sunyani and its environs (second } \\
\text { group) }\end{array}$ & 3 & 170.50 & 511.50 \\
$\begin{array}{c}\text { Kumasi and its environs (first } \\
\text { group) }\end{array}$ & 3 & 120.50 & 361.50 \\
$\begin{array}{c}\text { Kumasi and its environs (second } \\
\text { group) }\end{array}$ & 2 & 120.50 & 241.00 \\
$\begin{array}{c}\text { Kumasi and its environs (third } \\
\text { group }\end{array}$ & 2 & 570.50 & 1141.00 \\
Accra and its environs & 1 & 1020.50 & 1020.50 \\
\hline
\end{tabular}

Source: Authors' construct with data from the field survey, September, 2010 


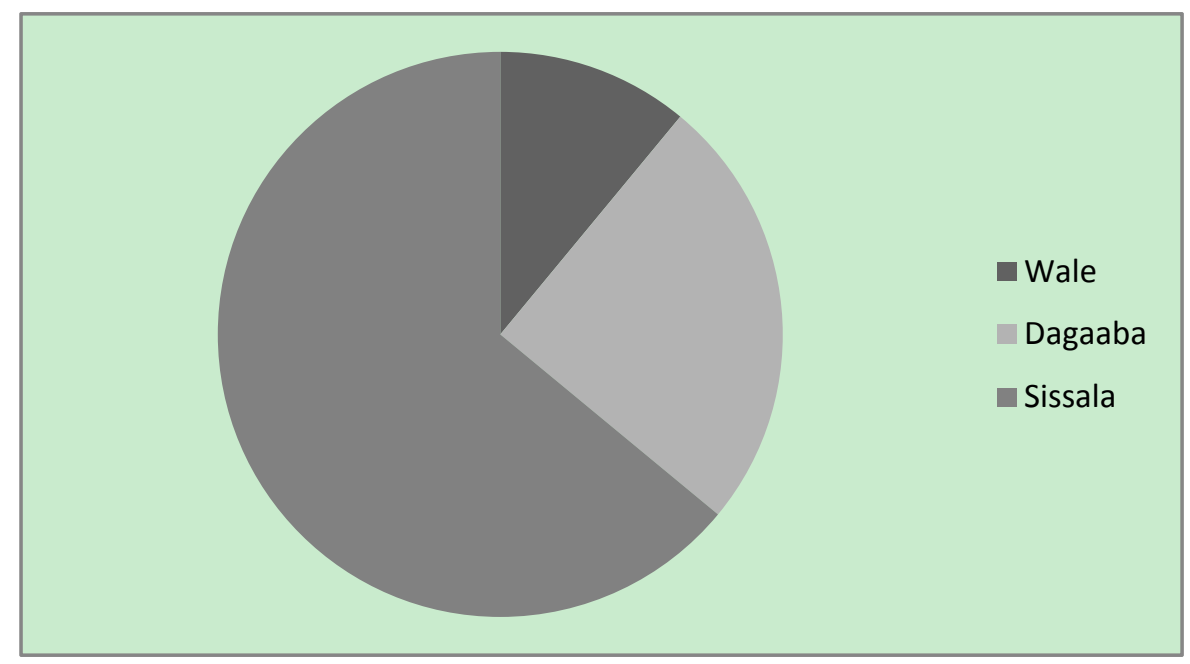

Figure 1. Ethnicity of charcoal producers
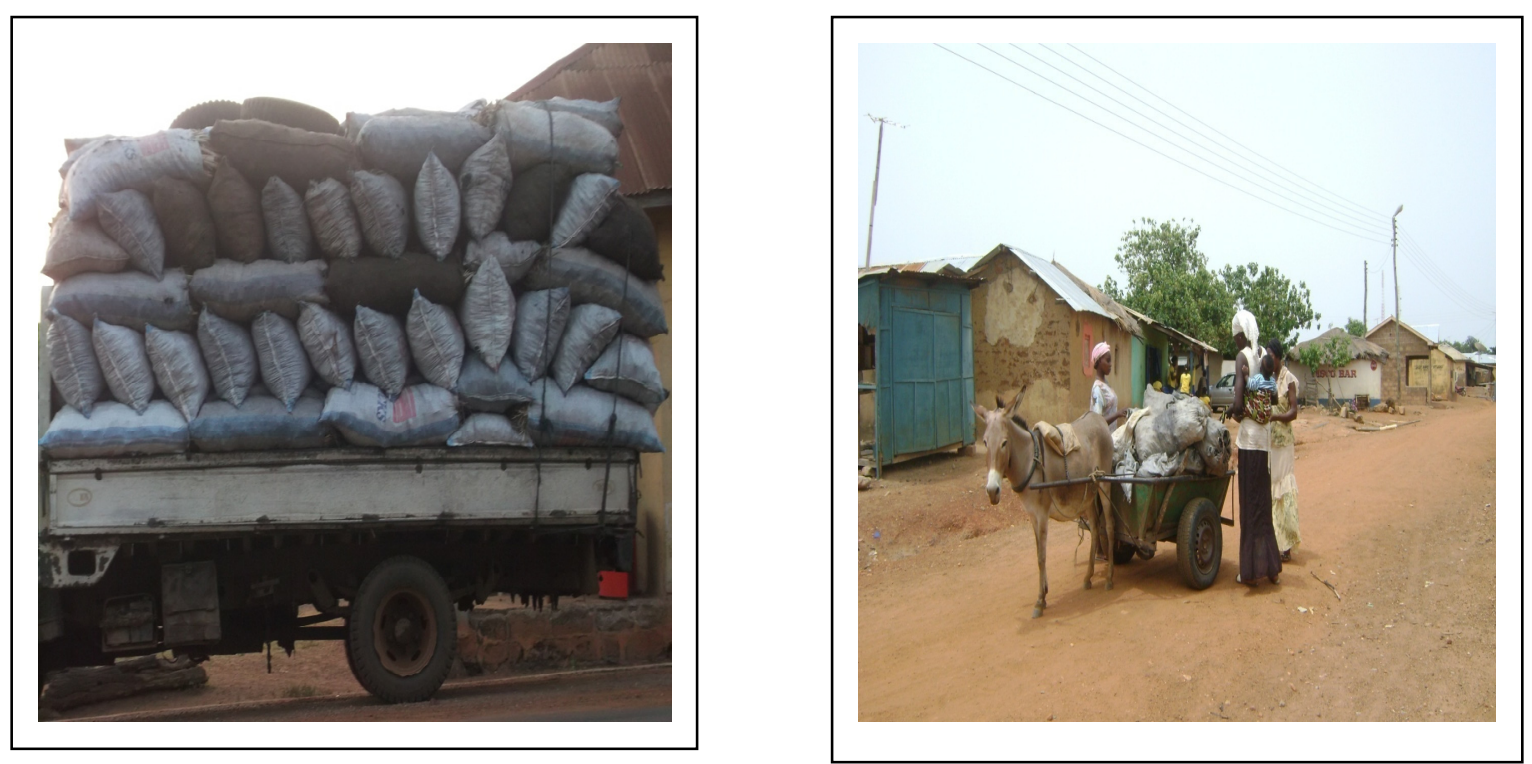

Figure 2. A KIA truck and donkey-drawn cart transporting charcoal
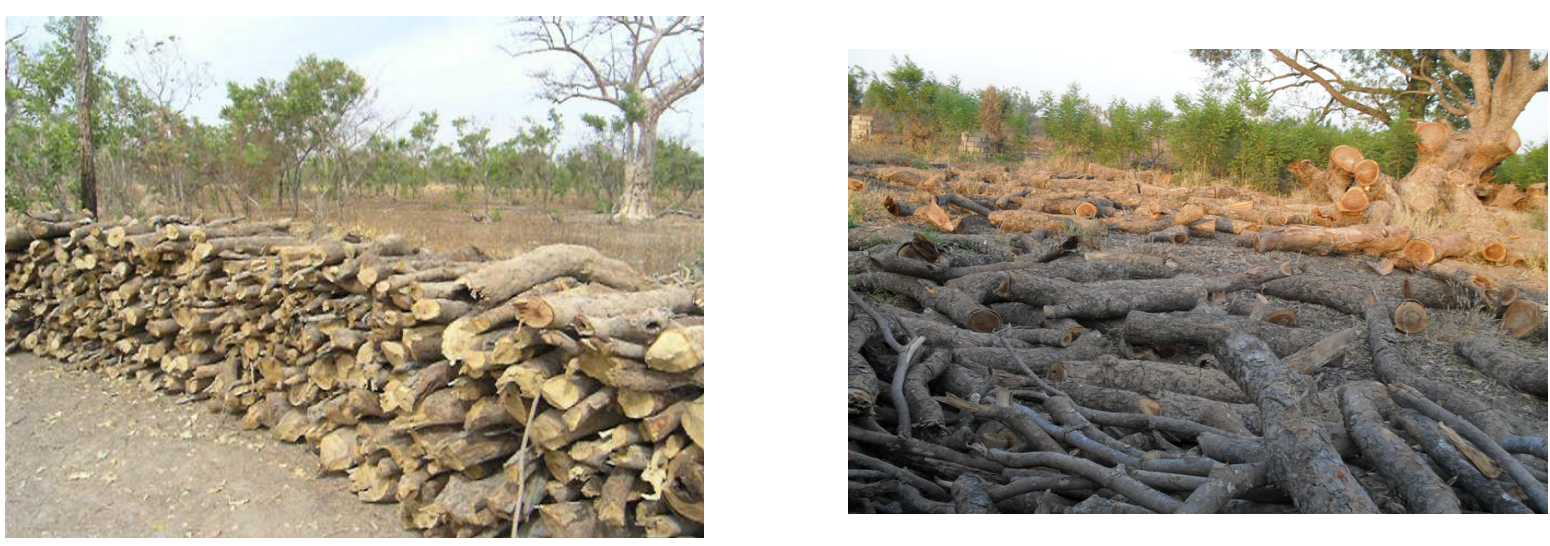

Figure 3. Logs harvested from the natural forest 

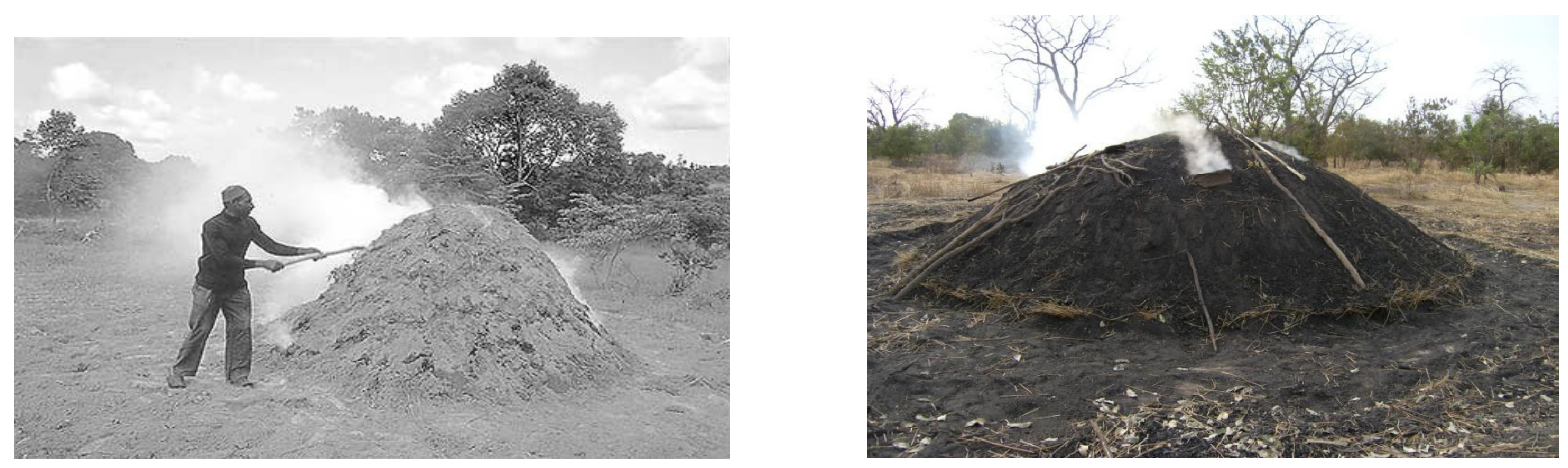

Figure 4. The Earth-Mound Method of Charcoal Production

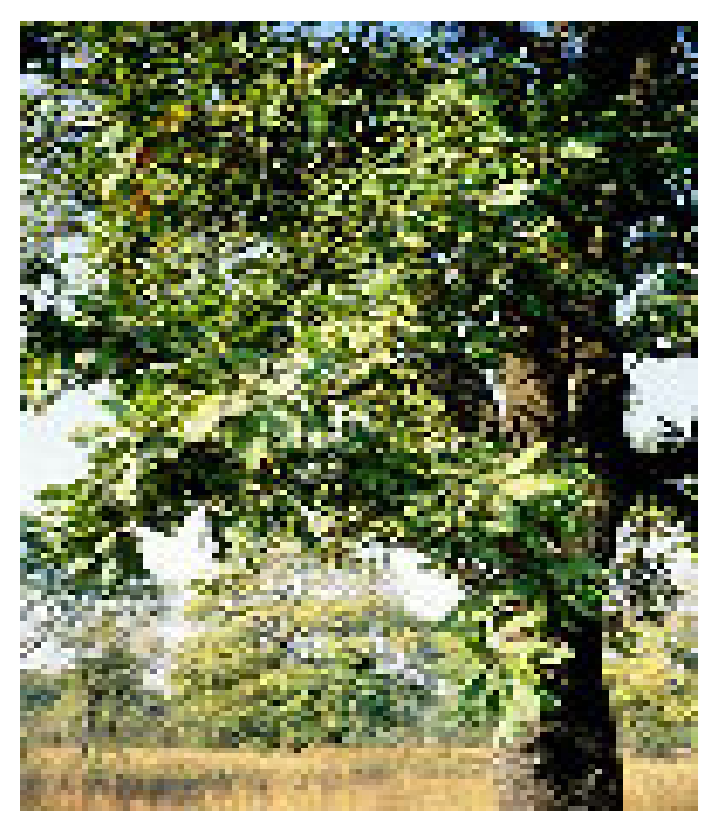

Figure 5. A matured shea tree 